Post peer review version of Maja Zehfuss, "The Tragedy of Violent Justice: The Danger of Elshtain's Just War Against Terror", International Relations, vol. 21, no. 4 (2007), pp. 493501. (ISSN 0047-1178)

Maja Zehfuss, The University of Manchester

\title{
The Tragedy of Violent Justice: The Danger of Elshtain's Just War Against Terror
}

Abstract: In Just War Against Terror Elshtain articulates emotions whilst ridiculing others who allegedly privilege emotion over reason. This critique focuses on her use of the notion of 'tragedy'. Distinctions are crucial to Elshtain's argument, especially that between combatants and civilians; they are based on significance of intention. Elshtain seems uneasy, however, about a particular consequence of waging war: civilian deaths. She seeks refuge in the notion of tragedy to characterise them; this reveals the complexity of the question of responsibility, which she does not however seriously engage. As a result, Elshtain's reasoning ends up implying a well-meaning but violent imperialism.

Key words: emotion, just war, imperialism, responsibility, tragedy, violence, war against terror Jean Bethke Elshtain's Just War Against Terror is a curious book. ${ }^{1}$ Although the idea that as an intellectual 'you have to be against it, whatever it is' incurs Elshtain's wrath, ${ }^{2}$ Just War Against Terror largely argues against: against naïve leftist intellectuals, against realitydenying clergy, against distinction-obliterators. Most curiously of all, Elshtain ridicules (some of) her opponents for privileging emotion over reason: in their 'subjectivist' perspective, she informs us, 'how I feel about something triumphs over serious thinking'. ${ }^{3}$ Yet at the same time she forcefully claims a right to her own feelings. She notes that '[a]nger remains an appropriate feeling $^{34}$ with respect to the events of September 11, 2001. Just War Against Terror certainly seems to be written in anger and indeed in exasperation, both about the naïveté of her fellow academics and the terrorists' failure to act within a definition of politics that Elshtain accepts. 
Just War Against Terror is clearly a polemic. This leaves the academic critic in a difficult position. There are contradictions in Elshtain's argument and one could laboriously dissect them, but that - it seems to me - would miss the point. Although framed in the tradition of just war thinking, Just War Against Terror does not really obey the rules of academic argument. Its power, such as it is, is performative. If readers are moved by this book, this is due to its passionate rhetoric, not its tight argument. My critique, therefore, zooms in on a particular rhetorical move that may appear to be marginal but that is at the same time revealing: the use of the notion of 'tragedy' in the context of violence and in particular of civilian deaths. What interests me then is not the validity or otherwise of Elshtain's claims, but rather the implications of the way in which she seems to seek refuge in the idea of tragedy in view of the adverse consequences of using violence.

\section{Just Distinctions}

Just war thinking is, as the name suggests, in the business of justifying war. It develops from the attempt to reconcile the need to use force with Christ's non-violent teachings. As Elshtain points out, the question of how a Christian can take up arms 'animated the just war tradition'. ${ }^{5}$ Elshtain notes that the 'presupposition of just war thinking is that war can sometimes be an instrument of justice; that, indeed, war can help to put right a massive injustice or restore a right order where there is disorder'. ${ }^{6}$ Thus, just war thinking confronts the problem of injustice in the world which, it is claimed, may (only) be rectified by force; it does not deny the ethically problematic consequences of war but argues that war is nevertheless, under the circumstances stipulated, justifiable and even just.

'Making the right distinctions' is crucial, Elshtain argues. ${ }^{7}$ She highlights in particular the significance of what is often referred to as 'discrimination' in just war thinking: the distinction between combatants, who may legitimately be targeted, and non-combatants, who may not. Elshtain is concerned, however, by the impossibility of altogether avoiding deaths, including those of civilians, in war: the 'question of "collateral damage" should never be taken lightly.' She emphasises that 'the United States takes this matter very seriously indeed' and that '[e]very incident in which civilian lives are lost is investigated and invokes a reevaluation of 
tactics in an attempt to prevent such incidents in future. ${ }^{8}$ Indeed, she claims that '[n]o institution in America pays more attention to ethical restraint on the use of force than does the U.S. military. ${ }^{9}$

At the same time, Elshtain is critical of the United States' tendency to endanger enemy civilians in an effort to reduce casualties among their own troops. With respect to other recent conflicts she describes as 'understandable' the 'preference to use airstrikes with precision, high-tech weaponry rather than pit more soldiers in harms way, ${ }^{10}$ but she also criticises this American overreliance on air power which she sees as not justifiable on just war grounds. ${ }^{11}$ It causes too many civilian casualties. She notes that '[a]ccording to just war thinking, it is better to risk the life of one's own combatants than those of enemy noncombatants. ${ }^{, 12}$ However, with respect to the current conflict she approves of US policy: 'The United States must do everything it can to minimize civilian deaths - and it is doing so. ${ }^{13}$ In other words, in Elshtain's view discrimination has been observed in the US 'war against terror' in Afghanistan. This is also the case with respect to Iraq. ${ }^{14}$

Although Elshtain concludes on the US 'war against terror' that 'every effort is being made to separate combatants from noncombatants, and that targeting civilians has been ruled out as an explicit war-fighting strategy,, ${ }^{15}$ she acknowledges that war nevertheless always affects civilians: 'Although civilian casualties should be avoided if at all possible, they occur in every war. ${ }^{, 16}$ Her argument with respect to this is interesting. Firstly, she seems to defer at least part of the responsibility for such casualties. She explains:

It is difficult to assess civilian casualties in a war theater, particularly in the patchwork that is Afghanistan, where different areas are under at least partial control of contesting tribal leaders (some of whom may have called in U.S. strikes against the Taliban when they were in fact trying to kill their own ethnic or tribal rivals, and this on more than one occasion). ${ }^{17}$ 
The assertion in brackets suggests that the casualties are not the Americans' responsibility but that of devious tribal leaders. Secondly, she notes that the 'Los Angeles Times concluded that the numbers suggest a very low casualty rate compared with earlier Afghan conflicts. $^{, 18}$ Thus, she uses previous warfare in Afghanistan as a comparative standard to establish the acceptability of the level of casualties. This does not seem to be in accordance with the just war criteria she outlines. There might, within just war thinking, be an acceptable casualty level determined by proportionality - 'the need to use the level of force commensurate with the nature of the threat ${ }^{19}$ - but this refers to the relation of the harm caused to the threat one is fighting, not to the local death rate previous to the conflict in question. In other words, under her own criteria Elshtain should not argue, as she seems to do, that it is all right to kill a few Afghanis as they are anyway in the habit of killing each other at a much higher rate.

It is, however, the third line of defence that is most interesting. Elshtain asserts that the US is not explicitly targeting non-combatants and that this is significant. Bin Laden does not distinguish between civilians and those in uniform. ${ }^{20}$ Whilst US 'military men understand that civilian death is an occasion for moral regret and a reexamination of strategy and tactics', ${ }^{21}$ the terrorists aim to kill civilians; they have no moral appreciation at all. It is curious that Elshtain uses this comparison: one would have thought that 'morally better than bin Laden' is not much of a standard to strive for. What is important, however, is why the deaths caused by the US and the terrorists are quite so morally different: both kill non-combatants knowingly but only the terrorists intend to kill them. Intention is both crucial to the distinction between just and unjust deaths and at the root of Elshtain's judgement that the terrorists are beyond politics.

Elshtain argues that bin Laden, with his failure to discriminate, strips civilians 'of their status as noncombatants and denies them the protection against intentional targeting and assault afforded anyone of that status by the laws of war. ${ }^{22}$ This means that he strips opponents of 'their very humanness. ${ }^{23}$ Elshtain notes: 'No political solution is possible [...] 
when the terrorism is aimed at the destruction of innocent civilians - when that itself is the goal. ${ }^{24}$ This means, in her view, that the terrorists 'have taken leave of politics. ${ }^{25}$ In other words, there 'is a nihilistic edge to terrorism: It aims to destroy, most often in the service of wild and utopian goals that make no sense at all in the usual political ways. ${ }^{26}$ Elshtain sums up her frustration in the rhetorical question:

What is one to do with the likes of bin Laden and Al Qaeda? They present no accountable, organized entity to engage - no sovereign state. They are not parties to any structure of diplomacy and thus cannot be negotiated with; in any event, because what they seek is destruction, there is nothing to negotiate about. ${ }^{27}$

Terrorism, Elshtain argues, is a form of extremism and this is why one cannot come to an arrangement with the terrorists. ${ }^{28}$ She accuses her opponents of failing to understand this because they are unable to make the appropriate and indeed crucial distinctions:

And if we cannot distinguish the killing of combatants from the intended targeting of peaceable civilians and the deliberate and indiscriminate sowing of terror among civilians, we live in a world of moral nihilism. In such a world, everything reduces to the same shade of grey and we cannot make distinctions that help us take our political and moral bearings. ${ }^{29}$

Again, intention is crucial to this assessment. Elshtain's argument is not about the fact of the killing of non-combatants, but about targeting them, about, in other words, intending to kill them. Driving this argument to its logical conclusion would mean to assert that intending to kill is worse than actual killing. So a planned attack against civilians that has not been executed would be morally worse than in fact, but unintentionally, killing civilians. When Elshtain compares two sets of actual killings, she sees a clear difference in how the people in question came to be dead. The issue is not so much that three thousand civilians died on September 11 whilst they were peacefully minding their own business; for Afghani and Iraqi 
'innocents' have surely been killed in much the same way by US and allied forces. It is that they were meant to be killed.

It is the insistence that the intention to kill civilians is the problem that lies behind Elshtain's complaint that it is 'both strange and disheartening to read the words of those distinction-obliterators for whom, crudely, a dead body is a dead body and never mind how it got that way. ${ }^{30}$ In other words, there is, in Elshtain's view, not merely a significant distinction based on who the dead were before they got that way - combatants or civilians - but also whether their deaths were intended or not. Her complaint against the terrorists is not only that they kill non-combatants - she acknowledges that so do, inevitably, US troops - but that they do so deliberately. Killing 'innocents' accidentally or even inevitably whilst targeting combatants or other appropriate military targets may be just; intending to kill them is not.

\section{The Tragedy of Violence}

It would appear then that the US and its military are in the clear: they do not intend to kill civilians and so there is no problem with the justness of their actions. Yet, even though killing civilians accidentally may be justified, Elshtain notes that 'every civilian death is a tragedy'. ${ }^{31}$ And, presumably because civilian deaths will always happen in war, '[a]॥ violence, including the rule-governed violence of warfare, is tragic' ${ }^{32}$ Elshtain does not define what she means by 'tragic' and there does not seem to be a clear definition of tragedy on which we could rely in view of Elshtain's failure to provide her own.

Terry Eagleton comments that '[i]n everyday language, the word "tragedy" means something like "very sad",33 and indeed that "no definition of tragedy more elaborate than 'very sad' has ever worked. ${ }^{34}$ Thus, the only aspect of 'tragedy' that appears to be clear is that it is about something being emotionally upsetting. Elshtain's recognition of this is interesting in itself but, true to her assertion that how one feels about something should not interfere with 'serious thinking', she does not actually explore her own discomfort at the deaths she calls 'tragic'. Eagleton, however, also observes that 'surely tragedy involves more than this. ${ }^{35}$ Elshtain's comments on the tragedy of violence, then, draw attention to 
something more than that the deaths in question are sad, that someone somewhere will be mourning the dead. This impression is confirmed by the way in which Elshtain attaches the idea of tragedy to civilian deaths only. Soldiers' deaths, though surely sad for those who loved them, are not identified as tragic.

Elshtain's only further comments on tragedy take us back to the issue of intention. She argues that $\mathrm{H}$. Richard Niebuhr 'would have cautioned us against calling September 11 a tragedy'. This is because '[u]sually when a true tragedy occurs - a flood roars through a canyon, for instance, and kills vacationers - there is no one to punish. ${ }^{36}$ Unlike acts of terror, the flood is not 'planned' or 'humanly willed'. ${ }^{37}$ A tragedy, then, is marked by a lack of intentionality and will, possibly even of human agency, therefore removing it, significantly for Elshtain, from the realm of punishment. Yet, even though September 11 was not, in this view, a 'tragedy' (as it was planned), the deaths on that day were, according to Elshtain, 'tragic'. In fact, she claims that 'every civilian death is a tragedy'. ${ }^{38}$ Presumably, Elshtain does not mean to say that every civilian death is caused by something like a flood roaring through a canyon. Indeed, if every civilian death is a tragedy, then 'tragedy' cannot depend on a lack of intentionality, the unavailability of someone to punish: civilians do get killed intentionally, and indeed Elshtain forcefully argues that those who died on September 11 did.

Elshtain's appeal to the notions of the 'tragic' and 'tragedy' is marked by an intriguing inconsistency. She presents an argument that, she claims, is all about pre-established criteria, about justice being 'measured', ${ }^{39}$ about 'serious thinking'. ${ }^{40}$ It is perhaps peculiar that these claims to rationality and indeed reasonableness are made quite so passionately, quite so much in anger. Yet what is truly interesting is that in places the pretence of reasonableness falls away - and tragedy comes to be invoked. Although civilian deaths in a just war are, according to her own argument, justified, although we can work this out rationally, her ethical framework apparently fails to satisfy even Elshtain herself. The horror of these deaths remains. 
'Tragedy', then, is that which just war thinking has nothing to say about; it is where life interferes. Life interferes not least because the lives taken by just war are, in Judith Butler's words, 'grievable'. ${ }^{41}$ Adrian Poole notes that Greek tragedies 'portrayed the fate of famous men and women', not 'of nobodies like you and me'. ${ }^{42}$ Tragedy was about something special. Yet, despite the current overuse of the term, Poole claims that it has not lost all meaning. The word still ennobles, connoting prestige and conferring dignity. ${ }^{43}$ Indeed, '[t]ragedy is a precious word. We use it to confer dignity and value on violence, catastrophe, agony, and bereavement. "Tragedy" claims that this death is exceptional. ${ }^{44}$ Thus, whilst Elshtain, in claiming that every civilian death is tragic, seems to depart decisively from the idea that tragedy involves a somehow exceptional catastrophe, she does perhaps aim to confer dignity in noting tragedy. I do not take these deaths lightly, she seems to say; I do acknowledge the catastrophe of these deaths, the victims' humanness, the irreplaceability of these lives.

The claim of 'tragedy', however, does more. It seems to place the terrible event beyond our responsibility. 'Tragic' suggests something like 'unintentional, yet upsetting'; beyond control; not part of the plan. Oedipus, after all, made a serious effort to avoid doing what was foretold, and yet he could not escape his fate. His patricide was both inevitable and in some sense accidental. Poole notes that 'our notions of tragedy are bound up with ideas about accident. "Tragedy" may connote inevitability and "accident" chance, yet somehow they are embroiled with each other. ${ }^{45}$ And this seems pertinent in relation to Elshtain's representation of civilian deaths in just war as tragic. They are indeed represented as on the one hand inevitable - after all, war will cause deaths - and accidental - the US does not intend them, in fact makes every effort to prevent them. As war, even just war, inevitably causes such deaths this is an acknowledgment of the damage the course of action she supports will do. She seems to recognise that the dead are irreplaceable, that their deaths in some fundamental sense fail to make sense. These deaths are not necessary to what she represents as just, but inevitable in the context of it, and hence tragic. But these deaths are also tragedies waiting to happen in Poole's sense: they 'can be foreseen and prevented', ${ }^{46}$ 
though he acknowledges Oedipus might not have agreed with this assessment, given that all his efforts to do so proved fruitless.

It is precisely this fruitlessness of his efforts that makes Oedipus a tragic hero. Oedipus kills his father unknowingly, in error, accidentally. Yet Oedipus clearly feels guilt: after discovering what he has done, he blinds himself. Tragedies, as Poole point out, 'complicate the question of blame'. ${ }^{47}$ There is, not least, 'never a singular cause'. ${ }^{48}$ This does not mean an absolution from blame, however, but rather that we are always inevitably implicated: 'Not that tragedy makes us feel that we are all to blame, certainly not equally to blame. It is rather that we are connected, even interconnected by complex systems of cause and consequence, in which questions of innocence and guilt are all caught up and embroiled, and from which no one should expect to be exempted. ${ }^{49}$ Eagleton points out that in what he calls 'a classically tragic scenario' - and he provides the Allies' engagement in the Second World War as an example - we do not escape responsibility: 'Rather like Oedipus, one does not will what is injurious, while nevertheless accepting some responsibility for it. ${ }^{, 50}$

In contrast, in Elshtain's rendering, if civilian deaths in the US 'war against terror' are 'tragic' - that is, like a flood roaring through a canyon - there is no one who can be held responsible, no one who may be punished, as long as the precautions of discrimination were taken and the deaths were therefore unintended, not willed. For Elshtain, what seems to set apart tragic events from others is indeed that there is no one to punish. In other words, blame cannot be assigned. Thus, the implication of Elshtain's argument seems to be that those in a just war may kill without having to accept responsibility - the 'war against terror' is like a flood roaring through a canyon - and yet her invocation of tragedy says otherwise; for the tragedy is that we are responsible even for that which we have not willed.

\section{The Tragedy of Responsibility}

Eagleton insists that in tragedy 'the injurious remains injurious; it is not magically transmuted into good by its instrumental value. ${ }^{51}$ If there were such transmutation we would presumably lack a sense of tragedy - and rejoice in the good. Yet Elshtain is engaged in just such 
transmutation. She makes clear at the outset that the 'burden of the argument' is 'that we must and will fight - not in order to conquer any countries or to destroy peoples or religions, but to defend who we are and what we, at our best, represent. ${ }^{52}$ Yet self-defence is not all. Elshtain argues that US practices are superior to Afghani practices, in particular where it comes to the treatment of women. ${ }^{53}$ Whilst one may well agree with Elshtain that the United States' attitude towards women is infinitely preferable to that of the Taliban, what interests me here is the function of this point in her argument. Given that this praise for American principles, values and identity occurs as part of an argument designed to show that the "war against terror' is just, war is in effect justified not on the grounds of the stipulated criteria, but on that of the moral superiority of US practices.

So, if our values and practices are better than theirs, why stop with Afghanistan? Or, to fall back more clearly on the criteria used by Elshtain: if we must protect the innocent from certain harm, why stop with Iraq? And indeed Elshtain forcefully draws the conclusion that the United States must not stop there. She claims that with 'great power comes an even greater responsibility,' that of responding 'to the cries of the aggrieved. ${ }^{, 54}$ The United States did not want this job: 'The role of preventing or interdicting violence in other countries is not new to the United States; it was thrust upon the United States in 1989 when it became the world's only superpower. ${ }^{, 55}$ Elshtain is thinking big here: Not only should the US intervene on behalf of 'the aggrieved'; it also must stay on after the intervention. She illustrates this in relation to Afghanistan:

The implication of calls for American withdrawal is that it is preferable to pull up stakes and leave a people beleaguered and vulnerable to terrorist exploitation. This strategy of abandonment, often justified as a way to respect culture's 'difference,' is actually a counsel of indifference. To abandon beleaguered peoples is to give them less regard than they deserve. At the conclusion of World War II, with all its attendant horrors, Hannah Arendt insisted that human dignity needed a 
new guarantee. Providing that guarantee puts an enormous burden on those with power. $^{56}$

Although Nicholas Rengger is keen to separate this imperial thinking from Elshtain's just war argument, ${ }^{57}$ it seems to me that one actually follows directly from the other. If the innocent are to be protected from harm, as we define it, then there are countless opportunities for just war.

In other words, in Elshtain's argument, the US becomes the tragic hero that has an unwanted responsibility foisted upon it. There is no escape. Elshtain's argument implies the necessity of a well-meaning but violent imperialism. Yet it is not clear whether - much like a flood in a canyon - the US is not to blame for the destruction it wreaks in acting according to its fate or whether the tragedy in question is not one of being responsible - inevitably implicated - in that which one has not willed (but, in this case, knowingly accepted). By noting that which she is unable to absorb into her intellectual framework as 'tragedy', Elshtain opens the door to the complexity of life, without however thinking through what this means. As Michael Dillon points out, tragedy is 'concerned precisely with the condition in which we do not and cannot know what is correct in advance, and with how, nonetheless, we creatively work-out and work with our disclosure in the truth of that condition in order to live the free manifold of life itself. ${ }^{58}$ Elshtain, in contrast, claims to know and hence sees ethical value in making things better for others. Such attempts at imposing control on a world that is perceived as dangerous and as not obeying her notions of what might constitute proper politics will inevitably entail a violent imperialism. In this Elshtain seems to me to deny the very humanness of those she claims to wish to protect. There is a tension between what she thinks ought to be and the world she believes she confronts; this, perhaps, accounts for her palpable frustration. That she opts to resolve this tension in favour of an imperial violence is the danger of Just War Against Terror and its tragedy. 
1 Some of the ideas in this paper were first presented at the BISA Poststructural Politics Group Workshop "Bush-Blair: Resisting the Axis of Evil" at the University of Wales Aberystwyth in May 2005. For discussions about and comments on ideas in this article I would like to thank Will Bain, Ilan Baron, Cian O’Driscoll, Jenny Edkins, Stuart Elden, Andrew Linklater and Hidemi Suganami. Jean Bethke Elshtain, Just War Against Terror: The Burden of American Power in a Violent World (New York: BasicBooks, 2003), p. 71.

3 Ibid., pp. 72-3. Ibid., p. 7.

5 Ibid., p. 50.

$6 \quad$ Ibid

$7 \quad$ Ibid., p. 54.

$8 \quad$ Ibid., p. 66.

9 Ibid., pp. 66-7; see also pp. 68-9.

$10 \quad$ Ibid., pp. 68-9.

11 Ibid., p. 69. Ibid., p. 65. Ibid., p. 69. Ibid., p. 190. Ibid., p. 67. Ibid., p. 66. Ibid., p. 67. Ibid., p. 68. Ibid., p. 65. Ibid., pp. 5-6. Ibid., p. 5. Ibid., p. 10. Ibid. Ibid., p. 19. Ibid. Ibid. Ibid., p. 61. 


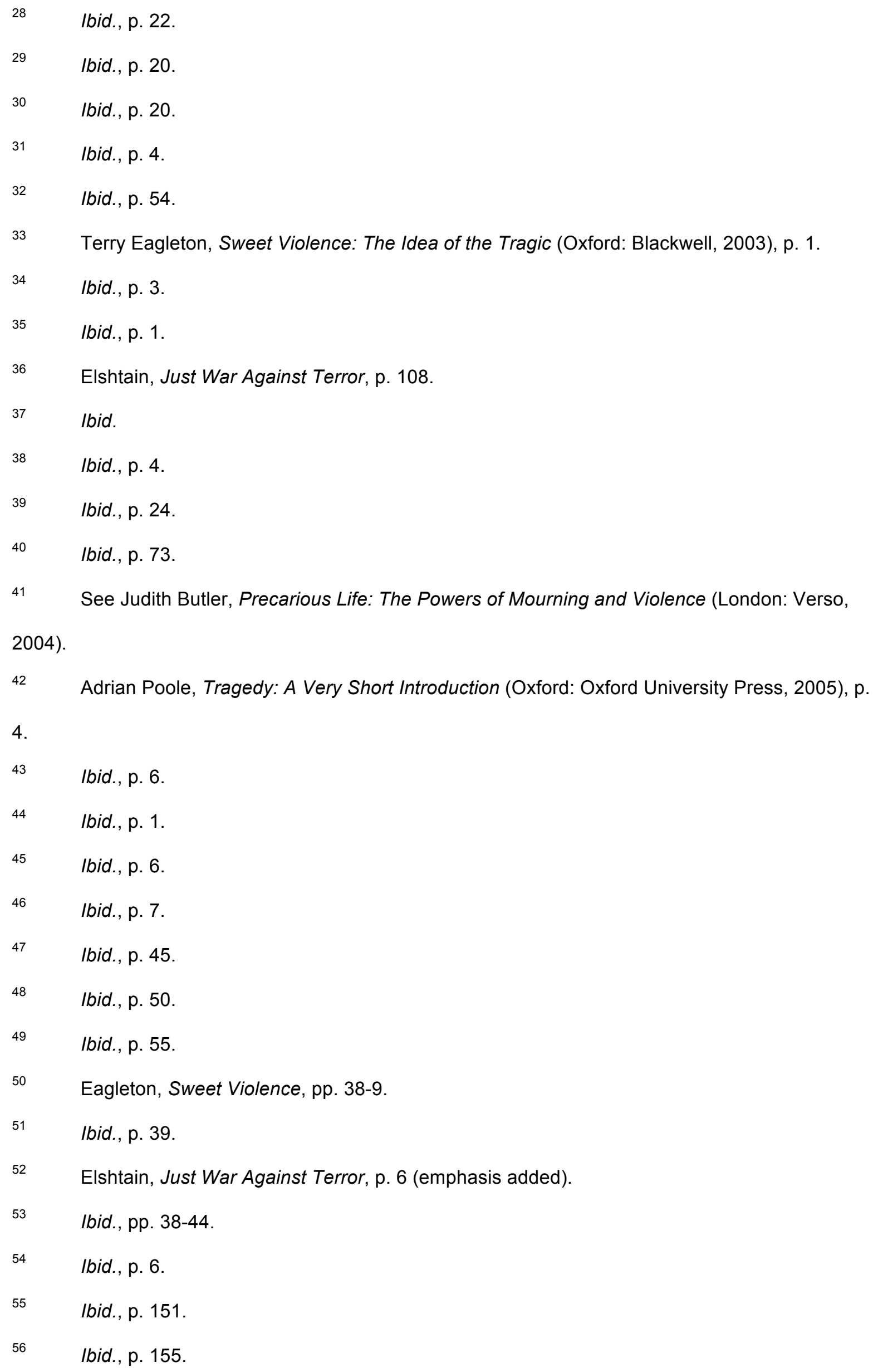
Ibid., p. 7. Ibid., p. 45. Ibid., p. 50. Ibid., p. 55. Eagleton, Sweet Violence, pp. 38-9. Ibid., p. 39. Elshtain, Just War Against Terror, p. 6 (emphasis added). Ibid., pp. 38-44. Ibid., p. 6. Ibid., p. 151. Ibid., p. 155. 
$57 \quad$ Nicholas Rengger, 'Just a war against terror? Jean Bethke Elshtain's burden and American power', International Affairs, 80 (1), 2004, esp. pp. 115-16.

58 Michael Dillon, Politics of Security: Towards a Political Philosophy of Continental Thought (London: Routledge, 1996), p. 145. 